\title{
Certified reference materials for radionuclides in Bikini Atoll sediment (IAEA-410) and Pacific Ocean sediment (IAEA-412)
}

Pham, M. K.; van Beek, P.; Carvalho, F. P.; Chamizo, E.; Degering, D.; Engeler, C.; Engeler, C.; Gurriaran, R.; Hanley, O.; Harms, A. V.

Total number of authors:

34

Published in:

Applied Radiation and Isotopes

Link to article, DOI:

10.1016/j.apradiso.2015.11.041

Publication date:

2016

Document Version

Peer reviewed version

Link back to DTU Orbit

Citation (APA):

Pham, M. K., van Beek, P., Carvalho, F. P., Chamizo, E., Degering, D., Engeler, C., Engeler, C., Gurriaran, R., Hanley, O., Harms, A. V., Herrmann, J., Hult, M., Ikeuchi, Y., Ilchmann, C., Kanisch, G., Kis-Benedek, G.

Kloster, M., Laubenstein, M., Llaurado, M., ... Zhou, W. (2016). Certified reference materials for radionuclides in Bikini Atoll sediment (IAEA-410) and Pacific Ocean sediment (IAEA-412). Applied Radiation and Isotopes, 109, 101-104. https://doi.org/10.1016/j.apradiso.2015.11.041

\section{General rights}

Copyright and moral rights for the publications made accessible in the public portal are retained by the authors and/or other copyright owners and it is a condition of accessing publications that users recognise and abide by the legal requirements associated with these rights.

- Users may download and print one copy of any publication from the public portal for the purpose of private study or research.

- You may not further distribute the material or use it for any profit-making activity or commercial gain

- You may freely distribute the URL identifying the publication in the public portal 
Certified Reference Materials for radionuclides in Bikini Atoll sediment (IAEA-410) and Pacific Ocean sediment (IAEA-412)

M.K. Pham ${ }^{\mathrm{a} @}$, P. van Beek ${ }^{\mathrm{b}}$, F.P. Carvalho ${ }^{\mathrm{c}}$, E. Chamizo ${ }^{\mathrm{d}}$, D. Degering ${ }^{\mathrm{e}}$, C. Engeler ${ }^{\mathrm{f}}$, C. Gascó ${ }^{\mathrm{g}}$, R. Gurriaran $^{\text {h }}$, O. Hanley ${ }^{\mathrm{i}}$, A.V. Harms ${ }^{\mathrm{a}}$, J. Herrmann ${ }^{\mathrm{j}}$, M. Hult ${ }^{\mathrm{k}}$, Y. Ikeuchi ${ }^{1}$, C. Ilchmann ${ }^{\mathrm{m}}$, G. Kanisch ${ }^{\mathrm{n}}$, G. Kis-Benedek ${ }^{0}$, M. Kloster ${ }^{\mathrm{m}}$, M. Laubenstein ${ }^{\mathrm{p}}$, M. Llaurado ${ }^{\mathrm{q}}$, J.L. Mas ${ }^{\mathrm{r}}$, M. Nakano ${ }^{\mathrm{s}}$, S.P. Nielsen ${ }^{\mathrm{t}}$, I. Osvath $^{\mathrm{a}}$, P.P. Povinec $\mathrm{u}$, U. Rieth ${ }^{\mathrm{v}}$, J. Schikowski ${ }^{\mathrm{x}}$, P.A. Smedley ${ }^{\mathrm{z}}$, M. Suplinska ${ }^{\mathrm{a}}$, S. Tarjan ${ }^{\mathrm{n}}$, B. Varga $^{\text {ab }}$, E. Vasileva ${ }^{\mathrm{a}}$, T. Zalewska ${ }^{\mathrm{ac}}$, W. Zhou ${ }^{\text {ad }}$

${ }^{a}$ International Atomic Energy Agency (IAEA), Environment Laboratories (EL), MC 98000, Monaco

${ }^{b}$ LEGOS/LAFARA, Observatoire Midi Pyrénées, 14 avenue Edouard Belin, 31400 Toulouse, France

${ }^{c}$ Instituto Superior Técnico/Instituto Tecnológico e Nuclear, P- 2685-953 Sacavém, Portugal

${ }^{d}$ Centro Nacional de Aceleradores (U. Sevilla, J. Andalucía, CSIC), Isla de la Cartuja, 41092 Sevilla, Spain

${ }^{e}$ Verein für Kernverfahrenstechnik und Analytik Rossendorf e.V, Postfach 510119, 01314 Dresden, Germany

${ }^{f}$ Rijkswaterstaat Centre for Water Management, Zuiderwagenplein 2, NL-8224 AD Lelystad, The Netherlands

${ }^{g}$ CIEMAT (RAyVR), Avda de la Complutense 40. Madrid 28040, Spain

${ }^{h}$ IRNS/PRP-EVN/STEME/LMRE, Bat 501, Bois des Rames, 91400 Orsay, France

${ }^{i}$ Environmental Protection Agency, Office of Radiological Protection, 3 Clonskeagh Square, Clonskeagh Road, Dublin 14, Ireland

${ }^{j}$ Federal Maritime and Hydrographic Agency (FMHA), Radioactivity of the Sea, Wuestland 2, DE-22589 Hamburg, Germany

${ }^{k}$ EC-JRC, Institute for Reference Materials and Measurements (IRMM), Retieseweg 111, B-2440 Geel, Belgium

${ }^{\prime}$ Japan Chemical Analysis Center, 295-3 Sanno-cho, Inage-ku, Chiba-shi, Chiba 263-0002, Japan

${ }^{m}$ Senatsverwaltung für Stadtentwicklung und Umwelt Strahlenmessstelle Rubensstraße 111-113, D-12157 Berlin, Germany

${ }^{n}$ Thünen Institute of Fisheries Ecology, 20539 Hamburg, Germany

${ }^{o}$ IAEA Environment Laboratories, Terrestrial EnviromentLaboratory, A-2444 Seibersdorf, Austria ${ }^{p}$ Laboratori Nazionali del

Gran Sasso, S.S. 17/bis km 18+910, I-67100 Assergi (AQ), Italy

${ }^{q}$ Lab. de Radiologia Ambiental, Dept. de Quimica Analitica, Facultat de Quimica, Universitat de Barcelona, 08028

Barcelona, Spain

${ }^{\mathrm{r}}$ Servicio de Radioisotopos, CITIUS, Avda. Reina Mercedes 4B, 41012 Sevilla, Spain

${ }^{s}$ Japan Atomic Energy Agency, 4-33, Muramatsu, Tokai-mura, Naka-gun, Ibaraki, 319-1194, Japan

${ }^{t}$ Center for Nuclear Technologies, Technical University of Denmark, 4000 Roskilde, Denmark

${ }^{u}$ Dept. of Nuclear Physics and Biophysics, Cornenius University, Mlynska dolina F1, Bratislava, Slovakia

${ }^{v}$ Landesmessstelle für Radioaktivität, Institut für Hygiene und Umwelt, Marckmannstraße 129, 20539 Hamburg, Germany

${ }^{x}$ Physikalische Chemie, Isotopenlabor, Tammannstrabe 6, 37077 Göttingen, Germany

${ }^{z}$ CEFAS, Lowestoft Laboratory, Lowestoft, Suffolk NR33 OHT, United Kingdom

${ }^{a}$ Central Laboratory for Radiological Protection, Konwaliowa 703-194 Warsaw, Poland

${ }^{a b}$ National Food Chain Safety Office, Food and Feed Safety Directorate, Hungary

${ }^{a c}$ Institute of Meteorology and Water, Management- National Research Institute, Maritime Branch, Waszyngtona 42, 81-342 Gdynia, Poland

${ }^{\text {ad }}$ Institute of Earth Environment, Chinese Academy of Sciences, 10 Fenghui South Road, High-Tech Zone, Xi'an, 710075.

P.R. China

@

\section{Abstract}

Certified Reference Materials (CRMs) for radionuclides in sediments from the Bikini Atoll (IAEA-410) and Pacific Ocean (IAEA-412) are described and the results of the certification process are presented. The CRMs can be used for Quality Assurance/Quality Control of analysis of radionuclides in sediments, as well as for development and validation of analytical methods, and for training purposes.

\section{Introduction}


Accurate and precise determination of radionuclide concentrations in marine samples is important for marine radioactivity assessments and for the use of radionuclides in the study of oceanographic processes. To address the problem of data quality, the IAEA's Environment Laboratories (IAEA-EL) in Monaco have conducted inter-laboratory comparison exercises on determinations of radionuclides in marine samples for almost fifty years as part of their contribution to the IAEA's programme of Analytical Quality Control Service (AQCS), now renamed as “IAEA’s Reference Products for Science and Trade” (Povinec and Pham, 2001; Sanchez-Cabeza et al., 2008). An important part of this activity was the production of Reference Materials (RMs), which were usually products of worldwide inter-laboratory comparison exercises. The IAEA's Reference Products for Science and Trade programme has recently focused on the production of Certified Reference Materials (CRMs) (ISO, 2006; Pham et al., 2006; 2008, 2014, Povinec and Pham, 2001, Sanchez-Cabeza et al., 2008) to improve the accuracy and precision of analyses, and to provide traceability to SI units. CRMs are valuable standards for method development and validation: they can indicate the need to improve or change existing methods and/or the need for further training. In fact, reference methods should only be accepted on the basis of inter-laboratory comparison tests performed on selected CRMs. RMs and CRMs should be available for all important marine matrices, such as sediment, biota, sea water, suspended matter, etc.

The production of a new reference material is a long process, covering the identification of needs, sample collection, pre-treatment, physical homogenization, bottling, homogeneity test, distribution to laboratories, evaluation of data, preliminary reporting, additional analyses by expert laboratories, certification of material (including the determination of proper values and their uncertainties), and finally issuing the RMs/CRMs.

These works were performed on sediment materials collected from the Bikini Atoll and Pacific Ocean. Participating laboratories were requested to determine as many anthropogenic and natural radionuclides as possible by gamma-spectrometry, alpha-spectrometry, beta- 
counting and/or mass spectrometry. The certification processes were completed and the materials will be issued as CRMs for radionuclides in sediment matrix.

\section{Experimental}

\subsection{Description of the material}

A total mass of $70 \mathrm{~kg}$ of wet sediment sample was sampled at $11^{\circ} 26^{\prime} \mathrm{N}, 164^{\circ} 52^{\prime} \mathrm{E}$ in the Bikini Atoll on 10 November 1997, by box coring at 0-24 m depth mixture. A total mass of $110 \mathrm{~kg}$ of wet sediment sample was sampled at $22^{\circ} 22^{\prime} \mathrm{N}, 152^{\circ} 40^{\prime} \mathrm{E}$ in the Pacific Ocean on 16 November 1997, by box coring at 0-35 m depth mixture. The sediments were first air-dried and subsequently heated in cabinets at $85^{\circ} \mathrm{C}$. The samples were then ground into powders, sieved through a $250 \mu \mathrm{m}$ sieve, homogenized by mixing in a nitrogen atmosphere, bottled and sealed in polyethylene flasks (100 g units) and coded as IAEA-410 for Bikini Atoll and IAEA-412 for Pacific Ocean, respectively. Totals of 150 bottles for IAEA-410 and 175 bottles of IAEA-412 were produced. All bottles were sterilized at $10 \mathrm{kGy}\left({ }^{60} \mathrm{Co}\right)$ at an irradiation facility (Isotron, France). The moisture content of the sample was found to be approximately $2-3 \%$.

\subsection{Sample dispatch and data feedback}

The test materials were distributed to 30 laboratories in February 2013. Each participant received a single bottle of each type of sediment. Twenty-six laboratories reported their results. For each radionuclide analysed, the following information was requested from participating laboratories: (1) average weight of sample used for analysis; (2) number of analyses; (3) massic activity (Bq kg${ }^{-1}$ ) corrected for blank, background, etc.; (4) estimation of the combined uncertainties; (5) description of chemical procedures and counting equipment; (6) standard solutions used for analysis; (7) chemical recoveries (if any), counting time and decay corrections. The reference date for reporting activities was $1^{\text {st }}$ January 2013. 


\subsection{Data treatment}

The calculation of the property values for the massic activities of anthropogenic and natural radionuclides was based on the assumption of non-parametric distribution of data to which distribution-free statistics are applicable. Laboratories' means and their uncertainties were calculated either as arithmetic means with corresponding standard deviations, if more than two results were reported, or as weighted means with weighted uncertainties in the case of only two results reported. The values below the limit of detection were segregated from the results and the remaining values were checked for the presence of outliers using a Box and Whisker plot test. Median values were calculated from all laboratories' means passing the test, rounded off to the most significant number. These values were considered to be the most reliable estimate of the property values. Confidence intervals were taken from a nonparametric sample population representing a two-sided interval at 95\% confidence limits.

\subsection{Criteria for certification}

The certification process was carried out following the ISO Guide 35 (ISO, 2006). For data sets comprising five or more accepted laboratories' means, the median activities (after rejection of outliers) were chosen as the best estimator of the property values. They were reported as “certified values” (Pham et al., 2006, 2008, 2014), if (i) at least five laboratories’ means were available, calculated from at least three different laboratories, (ii) the overall uncertainty did not exceed $\pm 5 \%$ for activities higher than $100 \mathrm{~Bq} \mathrm{~kg}^{-1}, \pm 10 \%$ for activities from 1 to $100 \mathrm{~Bq} \mathrm{~kg}{ }^{-1}$ and $\pm 20 \%$ for activities lower than $1 \mathrm{~Bq} \mathrm{~kg}^{-1}$.

An activity value was considered as an "information value" when at least five laboratories' means calculated from the results of at least two different laboratories were available and the condition (ii) for overall uncertainties was not satisfied.

Evidence of metrological traceability to the SI units was provided by all laboratories in their reports. 


\section{Results and discussion}

\subsection{Homogeneity tests}

For both sediments, the material's homogeneity was evaluated for ${ }^{40} \mathrm{~K},{ }^{137} \mathrm{Cs},{ }^{210} \mathrm{~Pb}$ $\left({ }^{210} \mathrm{Po}\right),{ }^{214} \mathrm{Bi},{ }^{214} \mathrm{~Pb},{ }^{226} \mathrm{Ra},{ }^{228} \mathrm{Th},{ }^{230} \mathrm{Th},{ }^{232} \mathrm{Th}$, U isotopes and ${ }^{239+240} \mathrm{Pu}$ activities based on measurements by high-resolution low-background gamma-spectrometry, alpha-spectrometry and mass spectrometry. The first homogeneity test between bottles was done for 14 aliquots chosen at random at different masses of samples (100 $\mathrm{g}$ for gamma spectrometry and between 1.5 and 10 g for alpha spectrometry and mass spectrometry). The second test within bottles was done for another 10 aliquots at $0.5-3 \mathrm{~g}$ of sample for Pu isotopes analysis by accelerator mass spectrometry (AMS) and $0.5 \mathrm{~g}$ of material for $\mathrm{U}$ isotopes determination using ICP-MS, respectively. Homogeneity was tested by using one-way analysis of variance. The coefficient variation was below $15 \%$ - 20\% for all radionuclides determined, depending on their activity range. The "between samples" variances showed no significant differences from the "within sample" variances for the radionuclides tested. The material can be considered homogeneous based on the heterogeneity tests at the different mass levels for the radionuclides mentioned above. An additional homogeneity test for major and trace elements (P, S, Cl, K, Ca, Fe, Ni, $\mathrm{Cu}, \mathrm{Zn}, \mathrm{As}, \mathrm{Br}, \mathrm{Sr}, \mathrm{I}, \mathrm{Ba}$ and $\mathrm{Pb}$ ) was done by XFR analysis on $4 \mathrm{~g}$ samples. The coefficient of variation was below $10 \%$ for XRF determined elements.

\subsection{Radionuclides with certified and information values}

\subsubsection{IAEA-410 (sediment from Bikini Atoll)}

The list of certified and information values for different radionuclides in IAEA-410 are showed in Table 1, where certified values are given for ${ }^{40} \mathrm{~K},{ }^{210} \mathrm{~Pb}\left({ }^{210} \mathrm{Po}\right),{ }^{239+240} \mathrm{Pu}$ and ${ }^{241} \mathrm{Am}$, and information values are given for ${ }^{137} \mathrm{Cs},{ }^{226} \mathrm{Ra},{ }^{228} \mathrm{Ra},{ }^{228} \mathrm{Th},{ }^{230} \mathrm{Th},{ }^{232} \mathrm{Th},{ }^{234} \mathrm{Th}$, ${ }^{234} \mathrm{U},{ }^{235} \mathrm{U},{ }^{238} \mathrm{U},{ }^{238} \mathrm{Pu},{ }^{239} \mathrm{Pu}$ and ${ }^{240} \mathrm{Pu}$. As the sample was collected in the Bikini Atoll, 
elevated levels of long-lived anthropogenic radionuclides such as Plutonium and Americium isotopes were expected due to the influence of the historical atmospheric nuclear weapons tests.

\subsubsection{IAEA-412 (sediment from Pacific Ocean)}

The list of certified and information values for different radionuclides in IAEA-412 are showed in Table 2, where certified values are given for ${ }^{40} \mathrm{~K},{ }^{137} \mathrm{Cs},{ }^{210} \mathrm{~Pb}\left({ }^{210} \mathrm{Po}\right),{ }^{226} \mathrm{Ra}$, ${ }^{228} \mathrm{Th},{ }^{232} \mathrm{Th},{ }^{239} \mathrm{Pu},{ }^{240} \mathrm{Pu}$ and ${ }^{239+240} \mathrm{Pu}$ radionuclides were certified, and the information values are given for ${ }^{228} \mathrm{Ra},{ }^{230} \mathrm{Th},{ }^{234} \mathrm{Th},{ }^{234} \mathrm{U},{ }^{235} \mathrm{U},{ }^{238} \mathrm{U},{ }^{238} \mathrm{Pu}$ and ${ }^{241} \mathrm{Am}$. As the sample was collected in the Pacific Ocean, elevated level of long-lived anthropogenic radionuclide such as

${ }^{137} \mathrm{Cs}$ was expected due to the influence of the historical atmospheric nuclear weapons tests.

It's worthy to notice that for ${ }^{239+240} \mathrm{Pu}$, a reasonable agreement was obtained between the results obtained by alpha-spectrometry and mass spectrometry for both samples: The combined ${ }^{239} \mathrm{Pu}$ and ${ }^{240} \mathrm{Pu}$ values obtained by the laboratories using ICP-MS and AMS were in agreement with the ${ }^{239+240} \mathrm{Pu}$ values obtained by alpha-spectrometry (Table 1 and Table 2)

\subsection{Disequilibrium in natural decay series}

Disequilibrium was found for the uranium series, especially for sediment from Bikini Atoll with ${ }^{230} \mathrm{Th}$ levels much higher than ${ }^{234} \mathrm{U},{ }^{226} \mathrm{Ra}$ and ${ }^{210} \mathrm{~Pb}\left({ }^{210} \mathrm{Po}\right)$ levels. This is expected, as thorium is a particle reactive element and its bioavailability is relatively low. No disequilibria were found for the thorium series in any of the two sediments.

\section{Conclusion}

The certification process, following ISO Guidelines 35, for new candidates of reference materials for radionuclides in sediments collected from the Bikini Atoll (IAEA-410) and Pacific Ocean (IAEA-412) has been performed through inter-laboratory comparison exercises. The CRMs can be used for Quality Assurance/Quality Control of analysis of 
radionuclides in sediments, as well as for development and validation of analytical methods, and for training purposes. The CRMs are available from the IAEA in $100 \mathrm{~g}$ units and can be ordered through the IAEA website (http://nucleus.iaea.org/rpst/).

\section{Acknowledgments}

The International Atomic Energy Agency is grateful to the participants and laboratories taking part in this inter-laboratory comparison and contributing their time and facilities to the present work. Special thanks are given to the Japan Meteorological Agency and Tokai University (Japan) for providing the cruise support for the expedition of IAEA’97 with R/V Bosei Maru in the Pacific Ocean in 1997. The International Atomic Energy Agency is grateful to the Government of the Principality of Monaco for the support provided to its Environment Laboratories. 


\section{References}

ISO, International Organization for Standardization, 2006. ISO Guide 35 Certification of Reference Materials - General and Statistical Principles. ISO, Geneva.

Pham, M.K., et al. 2006. Certified reference material for radionuclides in fish flesh sample IAEA-414 (mixed fish from the Irish Sea and North Sea). Appl. Radiat. Isot.64, 1253-1259.

Pham, M.K., et al., 2008. A new Certified Reference Material for radionuclides in Irish Sea Sediment (IAEA-385). Appl. Radiat. Isot.66, 1711-1717.

Pham, M.K., et al., 2014. Certified Reference Material IAEA-446 for radionuclides in Baltic Sea seaweed. Appl. Radiat. Isot.87, 468-474.

Povinec, P.P., and Pham, M.K., 2001. IAEA reference materials for quality assurance of marine radioactivity measurements. J. Radioanal. Nucl. Chem. 248, 211-216.

Sanchez-Cabeza, J.A., Pham, M.K., Povinec, P.P., 2008. IAEA programme on the quality of marine radioactivity data. J. Environ. Rad. 99, 1680-1686. 
Table 1. Certified and information massic activities in IAEA-410 Sediment from Bikini Atoll.

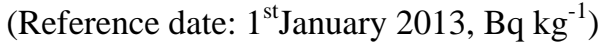

\begin{tabular}{cccc}
\hline Radionuclide & Median & $\begin{array}{c}\text { Confidence interval } \\
(\alpha=0.05)\end{array}$ & $\begin{array}{c}\text { Number } \\
\text { of results* }\end{array}$ \\
& & & \\
\hline & Certified value & & \\
${ }^{40} \mathrm{~K}$ & & & 22 \\
${ }^{210}{ }^{20}\left(^{210} \mathrm{Po}^{\$}\right.$ & 116 & $109-121$ & 19 \\
${ }^{239+240} \mathrm{Pu}^{+}$ & 232 & $221-238$ & 9 \\
${ }^{241} \mathrm{Am}$ & 4.69 & $4.52-4.92$ & 23 \\
& 4.10 & $3.77-4.15$ & \\
& & & 6 \\
${ }^{137} \mathrm{Cs}$ & Information value & & 16 \\
${ }^{226} \mathrm{Ra}$ & & & 13 \\
${ }^{228} \mathrm{Ra}$ & 0.19 & $0.15-0.24$ & 6 \\
${ }^{228} \mathrm{Th}$ & 207 & $189-220$ & 8 \\
${ }^{230} \mathrm{Th}$ & 7.7 & $7.0-9.3$ & 6 \\
${ }^{232} \mathrm{Th}$ & 8.3 & $6.7-9.5$ & 11 \\
${ }^{234} \mathrm{Th}$ & 449 & $358-510$ & 9 \\
${ }^{234} \mathrm{U}$ & 8.8 & $7.3-10.0$ & 15 \\
${ }^{235} \mathrm{U}$ & 10.5 & $7.9-16.0$ & 5 \\
${ }^{238} \mathrm{U}$ & 9.3 & $8.5-11.1$ & 5 \\
${ }^{238} \mathrm{Pu}$ & 0.39 & $0.30-0.45$ & \\
${ }^{239} \mathrm{Pu}$ & 9.0 & $8.1-10.1$ & \\
${ }^{240} \mathrm{Pu}$ & 0.059 & $0.050-0.084$ & $2.27-2.70$ \\
& 2.45 & $2.09-2.65$ & \\
\hline
\end{tabular}

* Number of accepted laboratory means which were used to calculate the certification and information values and the confidence intervals.

${ }^{\$ 210} \mathrm{~Pb}$ and ${ }^{210} \mathrm{Po}$ were considered as in equilibrium. 
Table 2. Certified and information massic activities in IAEA-412 Sediment from the Pacific Ocean.

(Reference date: $1^{\text {st January 2013, Bq kg }}{ }^{-1}$ )

\begin{tabular}{cccc}
\hline Radionuclide & Median & $\begin{array}{c}\text { Confidence interval } \\
(\alpha=0.05)\end{array}$ & $\begin{array}{c}\text { Number } \\
\text { of results* }\end{array}$ \\
\hline & Certified value & & \\
& & & \\
${ }^{40} \mathrm{~K}$ & 560 & $550-574$ & 18 \\
${ }^{137} \mathrm{Cs}$ & 6.54 & $6.25-6.87$ & 23 \\
$\left.{ }^{210} \mathrm{~Pb}{ }^{210} \mathrm{Po}\right)^{\$}$ & 105 & $103-107$ & 20 \\
${ }^{226} \mathrm{Ra}$ & 26.7 & $25.0-27.8$ & 11 \\
${ }^{228} \mathrm{Th}$ & 37.5 & $36.2-40.0$ & 8 \\
${ }^{232} \mathrm{Th}$ & 36.3 & $34.0-37.5$ & 9 \\
${ }^{239} \mathrm{Pu}$ & 0.36 & $0.34-0.37$ & 5 \\
${ }^{240} \mathrm{Pu}$ & 0.24 & $0.23-0.26$ & 5 \\
${ }^{239+240} \mathrm{Pu}$ & 0.61 & $0.58-0.63$ & 15 \\
& & & \\
& & & 13 \\
${ }^{228} \mathrm{Ra}$ & 36.5 & $34.0-40.2$ & 7 \\
${ }^{230} \mathrm{Th}$ & 28.0 & $18.3-32.0$ & 8 \\
${ }^{234} \mathrm{Th}$ & 36.1 & $30.5-44.6$ & 10 \\
${ }^{234} \mathrm{U}$ & 29.0 & $14.7-35.6$ & 11 \\
${ }^{235} \mathrm{U}$ & 1.5 & $1.3-1.7$ & 6 \\
${ }^{238} \mathrm{U}$ & 32.9 & $30.0-36.5$ & 7 \\
${ }^{238} \mathrm{Pu}$ & 0.020 & $0.015-0.026$ & \\
${ }^{241} \mathrm{Am}$ & 0.28 & $0.17-0.40$ & \\
& & & \\
\hline & & & \\
\hline
\end{tabular}

* Number of accepted laboratory means which were used to calculate the certification and information values and the confidence intervals.

${ }^{210} \mathrm{~Pb}$ and ${ }^{210} \mathrm{Po}$ were considered as in equilibrium. 